\title{
Prediction of Gross Extrathyroidal Extension Using Preoperative Ultrasonography in Papillary Thyroid Cancer
}

\author{
Hyo-Seok Seo ${ }^{1,2}$, Yong-Il Cheon ${ }^{1,2} \mathbb{D}$, Hyun-Keun Kwon ${ }^{1,2} \mathbb{D}$, Sung-Chan Shin ${ }^{1,2}$ (D), \\ Myeonggu Seo ${ }^{1,2}$, Youngjin Cho ${ }^{1,2}$, Eui-Suk Sung ${ }^{3} \mathbb{D}$, Jin-Choon Lee ${ }^{3} \mathbb{E}$, \\ Bo Hyun Kim ${ }^{4}$, In Ju Kim ${ }^{4}$, and Byung-Joo Lee ${ }^{1,2}$ D \\ ${ }^{1}$ Departments of Otorhinolaryngology-Head and Neck Surgery, ${ }^{4}$ Internal Medicine, Pusan National University Hospital, \\ Pusan National University School of Medicine, Busan; and \\ ${ }^{2}$ Biomedical Research Institude, Pusan National University Hospital, Busan; and \\ ${ }^{3}$ Department of Otorhinolaryngology-Head and Neck Surgery, Pusan National University Yangsan Hospital, \\ Pusan National University School of Medicine, Yangsan, Korea
}

수술 전 초음파를 통한 육안적 갑상선 피막 외 침윤의 예측

서효석 ${ }^{1,2} \cdot$ 천용일 $^{1,2} \cdot$ 권현근 $^{1,2} \cdot$ 신성찬 $^{1,2} \cdot$ 서명구 $^{1,2} \cdot$ 조영진 $^{1,2} \cdot$ 성의숙 $^{3} \cdot$ 이진춘 $^{3} \cdot$ 김보현 $^{4} \cdot$ 김인주 $^{4} \cdot$ 이병주 $^{1,2}$

부산대학교 의과대학 부산대학교병원 이비인후과학교실, ${ }^{1}$ 내과학교실, ${ }^{4}$ 부산대학교병원 의생명연구원, ${ }^{2}$

부산대학교 의과대학 양산부산대학교병원 이비인후과학교실 ${ }^{3}$

\author{
Received August 19, 2020 \\ Revised November 1, 2020 \\ Accepted November 4, 2020 \\ Address for correspondence \\ Byung-Joo Lee, MD, PhD \\ Department of Otorhinolaryngology- \\ Head and Neck Surgery, \\ Pusan National University \\ School of Medicine, \\ Pusan National University \\ and Biomedical Research Institute, \\ Pusan National University Hospital, \\ 179 Gudeok-ro, Seo-gu, \\ Busan 49241, Korea \\ Tel +82-51-240-7335 \\ Fax +82-51-246-8668 \\ E-mailvvoiceleebj@gmail.com
}

Background and Objectives The American Joint Committee on Cancer (AJCC) staging system 8th Edition has stated that gross extrathyroid extension (ETE) is more important than microscopic ETE, and that it plays an important factor in the classification of T stages. Therefore, the prediction of gross ETE before surgery is important in establishing the clinical stage and determining the surgical extent. However, there are few studies predicting gross ETE using preoperative ultrasonography (US). The purpose of this study is to predict the gross ETE of papillary thyroid carcinoma (PTC) using preoperative US.

Subjects and Method The preoperative US findings of 688 patients with PTC were compared with gross ETE confirmed during the surgery. The efficacy of preoperative US was statistically analyzed.

Results A total of $70(10 \%)$ patients were confirmed of their gross ETE. Thyroid tumors were classified into three groups (isolation, capsular contact, and capsular protrusion) according to their relationship with capsules, and evaluated using the preoperative US. There was a significant difference in gross ETE between groups $(p<0.001)$. The thyroid tumor that came into contact with the capsule or protruded in the anterior region showed a difference between the capsular contact and capsular protrusion groups $(p<0.001)$, whereas those came into contact with the capsule or protruded in the posterior region showed no significant difference between the two groups $(p=0.187)$. There was no difference in the degree of protrusion $(<25 \%$, $25-50 \%, \geq 50 \%$ ) in the capsular protrusion group ( $p=0.868)$, but the difference in tumor size was significant $(p<0.001)$.

Conclusion Preoperative US is a useful tool for predicting gross ETE and is more predictable when the thyroid tumor is located anteriorly. Korean J Otorhinolaryngol-Head Neck Surg 2021;64(10):734-40

Keywords Extrathyroidal extension; Papillary thyroid carcinoma; Predictive; Ultrasonography.

This is an Open Access article distributed under the terms of the Creative Commons Attribution Non-Commercial License (https://creativecommons.org/licenses/by-nc/4.0) which permits unrestricted non-commercial use, distribution, and reproduction in any medium, provided the original work is properly cited. 


\section{서 론}

분화 갑상선암(differentiated thyroid carcinoma)은 전체 갑상선암의 $90 \%$ 를 차치하고 있으며 그중 가장 흔한 형태는 갑상선 유두암(papillary thyroid carcinoma)이다. ${ }^{1)}$ 갑상선 유두암은 여성에게 호발하고 임파선 전이가 흔해 30 80\%에 이르며 비교적 예후가 좋아 10년 질병 특이 생존율은 $96 \%$ 로 보고된다. ${ }^{2,3}$ 갑상선 유두암은 진단 시 나이, 종물의 크기, 국소 임파선 전이와 원격 전이 등 지난 수십 년간의 연구를 통해 예후 인자 역시 잘 연구된 암이다. ${ }^{4)}$ 갑상선 유두암에서 피막 외 침윤(extrathyroidal extension) $)^{5)}$ 은 이환율과 사망률을 증 가시키는 독립적인 위험 인자이며 병기 설정과 수술 범위를 결정하는 중요한 인자이다. ${ }^{6}$

조직학적으로 피막 외 침윤은 침범의 정도에 따라 나누게 되며, 갑상선 종물이 주요 구조물을 침범한 정도가 수술 중 육안적으로 확인한 경우를 육안적 피막 외 침윤(gross extrathyroidal extension)이라고 하고, 수술 후 현미경적 조직 소견 에 의해 확인한 경우를 미세 피막 외 침윤(minor or microscopic extrathyroidal extension)이라고 한다.7) 미국 암 연합 위원회(American Joint Committee on Cancer staging system, AJCC) 8 판 ${ }^{8}$ 에서 미세 피막 외 침윤보다는 육안적 피막 외 침윤이 더 중요하다고 하였고, $\mathrm{T}$ 병기 분류의 중요한 인자 이다. 그래서 수술 전 육안적 피막 외 침윤의 예측은 임상적 병기 설정과 수술 범위 결정에 중요하다.

고해상도 초음파(high resolution ultrasonography)는 수술 전 갑상선 암을 평가함에 가장 유용한 도구로 알려져 있으며 미국 갑상선학회(American Thyroid Association, ATA)와 미국 종합 암 네트워크(National Comprehensive Cancer Network, $\mathrm{NCCN}$ )에서 추천하는 수술 전 표준 검사 방법이 다.,10) 수술 전 초음파를 이용한 피막 외 침윤에 대한 예측을 기존의 연구는 미세 피막 외 침윤을 포함하는 경우가 많았다. 수술 전 초음파를 이용하여 육안적 피막 외 침윤을 예측하려 는 연구는 미미하였다. 그래서 본 연구는 갑상선 유두암 환자 들의 수술 전 초음파 소견과 육안적 피막 외 침윤과의 상관 성을 분석하여 수술 전 초음파의 정확성과 예측에 관련되는 인자에 대해 분석하고자 한다.

\section{대상 및 방법}

\section{대 상}

본 연구는 2017년 1월 2019년 5월까지 부산대학교병원 이 비인후과에서 갑상선 절제술(thyroidectomy)을 시행한 환자 중 병리 검사에서 최종적으로 갑상선 유두암을 진단받은 환
자를 대상으로 진행하였다. 총 785 명의 환자 중 갑상선 유두 암이 아닌 환자, 완결 갑상선 절제술(completion thyroidectomy)을 받은 환자, 재발로 인해 재수술(revision thyroidectomy)을 받은 환자, 수술 전 초음파를 본원에서 시행하지 않 은 환자 및 진단 당시 18 세 미만인 환자를 제외한 688 명이 연 구에 포함되었다. 환자는 18 85세까지 분포하였고 평균 나이 는 50.0세, 남녀는 각각 129 명, 559명이며 수술 중 육안적 피 막 외 침윤을 보인 환자는 70명, 그렇지 않은 환자는 618명이 었다. 본 연구는 후향적 연구(retrospective study)이며 부산 대학교병원 기관윤리심의위원회의 심의를 통과하였다(승인 번호: 2003-016-089).

\section{방 법}

본원 내분비내과에서는 갑상선 절제술 시행 예정인 모든 환 자를 대상으로 술전 초음파를 시행하고 있다. 연구 대상자의 초음파 영상 자료와 의무기록을 수술 중 확인된 피막 외 침 윤과 후향적으로 비교 분석하였다. 초음파는 3 11 MHz의 선 형 송수파기(GE LOGIQ E9, GE Healthcare, Chicago, IL, USA) 또는 5 14 MHz의 송수파기(ACUSON S2000, $\mathrm{Sie}^{-}$ mens Healthineers, Malvern, PA, USA)를 사용하였고, 3년 이상의 경력을 가진 9 명의 본원 내분비내과 전문의 중 1 명에 의해 시행되었다. 초음파 영상의 분석은 25 년 이상의 경력을 가진 1 명의 이비인후과 전문의(술자)가 분석하였다. 영상은 종물의 크기(mass size), 종물과 피막과의 관계(relationship with capsule), 종물과 피막이 접한 위치(contact site of capsule), 종물이 피막을 돌출한 정도(degree of protrusion)를 조사하여 육안적 피막 외 침윤 결과와 비교, 분석하였다. 또 한 연구대상자의 의무기록을 토대로 나이(age), 성별(sex), 키 (height), 몸무게(weight), 체질량 지수(body mass index, World Health Organization classification), 가족력(family history), 갑상선 염(thyroiditis) 유무, Korean Thyroid Imaging Reporting and Data System(K-TIRADS), BRAF 변이 유무, N stage, 수술 범위(extent of surgery)를 조사하여 각 인자(parameters)와 육안적 피막 외 침윤의 관계를 비교, 분석하였다.

종물의 크기는 $\mathrm{AJCC} 8$ 판 ${ }^{8}$ 의 T병기에 따라 $1 \mathrm{~cm}$ 이하, $1 \mathrm{~cm}$ 초과 $2 \mathrm{~cm}$ 이하인 경우, $2 \mathrm{~cm}$ 초과인 경우로 나누었다. 종물 과 갑상선 피막과의 관계는 종물이 정상 갑상선 실질 내에 국 한되어 피막과의 접촉이 없는 경우를 고립군(isolation)(Fig. 1), 종물과 갑상선 피막 사이에 정상 갑상선 실질이 보이지 않고 닿아 있으나 피막의 경계가 명확하고 정상의 갑상선 모양에서 종물이 돌출되지 않은 경우를 피막 접촉군(capsular contact) (Fig. 2), ${ }^{11)}$ 그리고 종물과 피막과의 경계 연속성이 단절되어 있고 정상의 갑상선 모양에서 종물이 돌출된 경우를 피막 돌 
출군(capsular protrusion)(Fig. 3)의 3개 군으로 나누었다.

종물과 피막이 접하거나 돌출한 경우는 전방(anterior region)과 후방(posterior region)으로 구분하였다. 전방은 띠 근육(strap muscle)과 접하는 경우이며, 후방은 기관(trachea), 식도(esophagus), 경동맥 초(carotid sheath) 또는 뒤쪽 연부 조직(soft tissue)과 접하는 경우로 정의하였다. 종물이 앞뒤 양측 모두 접하는 경우 양쪽 군에 모두 포함시켜 분석을 시 행하였다. 종물이 피막을 돌출한 정도는 초음파상 종물의 축 상(axial view) 단면적(cross-sectional area)에서 갑상선 피막 밖으로 돌출된 종물의 면적이 전체 종물 면적에서 차지하는 비율(protrusion ratio)에 따라 0에서 $25 \%$ 미만, $25 \%$ 이상에 서 $50 \%$ 미만, $50 \%$ 이상의 3군으로 나누었다(Fig. 4).

연구 대상자의 나이는 55세 미만과 55세 이상으로 나누었 고, 갑상선 염 유무의 확인은 병력과 최종 조직 검사 결과에 근거하여 조사하였다. $B R A F$ 유전자 변이 유무는 수술 전 본원 및 타병원에서 검사를 시행한 자에 한해 분석하였으며, $\mathrm{N}$ 병기는 최종 조직 검사 결과를 토대로 분석하였다. 수술 범 위는 종양에 대한 다양한 임상 인자, 반대편 엽의 상태, 환자 의 불안이나 요구 등을 고려하여 주로 내분비대사내과와 함

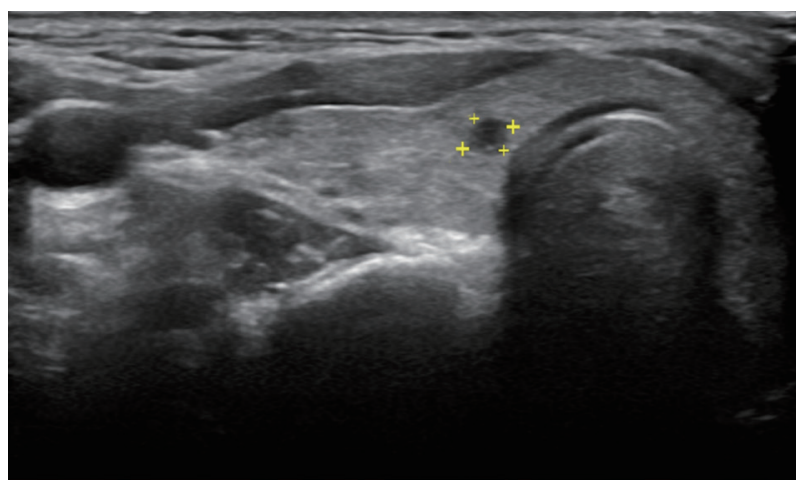

Fig. 1. Isolation. The mass is within the normal thyroid parenchyma.

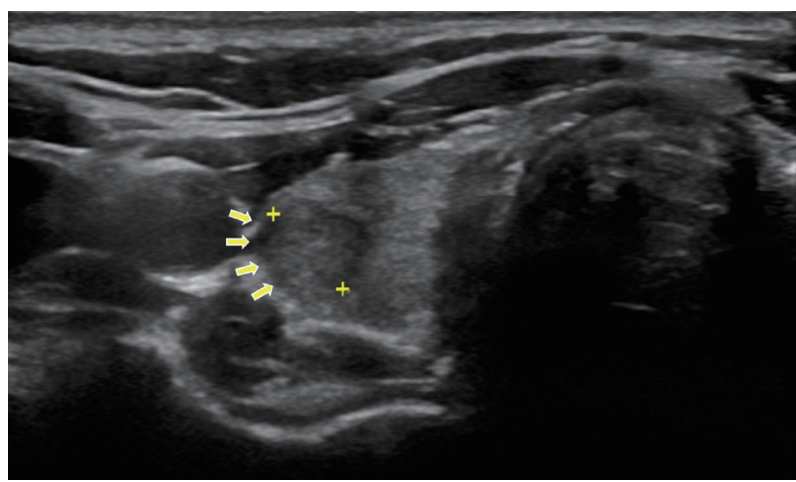

Fig. 2. Capsular contact (posterior region). There is no normal parenchyme between thyroid mass and thyroid capsule, but the perithyroidal echogenic line (arrows) between the site of thyroid mass and the thyroid capsule is clear and thyroid mass does not protrude out of the thyroid.
께 진행하는 수술 전 다학제를 통해 결정하였다. 수술은 갑 상선 엽절제술, 갑상선 전절제술, 경부 절제술을 포함한 갑상 선 전절제술(total thyroidectomy with lateral neck dissection)의 3군으로 나누었다. K-TIRADS는 2 4점 이하, 5점의 2군으로 나누었다.

\section{통계학적 분석}

SAS 9.4(SAS Institute Inc., Cary, NC, USA)를 이용하여 육안적 피막 외 침윤이 있는 군과 없는 군에서 각 매개 변수 를 비교하였으며, 연속형변수(numeric variable)는 독립 t-검 정(independent t-test) 또는 윌콕슨 순위합 검정(Wilcoxon rank-sum test)을 실시하고, 범주형변수(categorical variable)는 카이제곱검정(chi-square test) 또는 피셔의 정확 검정 (Fisher's exact test)을 유의수준 $5 \%(p<0.05)$ 에서 양측검정 으로 시행하였다. 수술 전 초음파 검사의 예측 효능(efficacy) 을 평가하기 위해 민감도(sensitivity), 특이도(specificity), 정 확도(accuracy), 양성예측도(positive predictive value), 음성 예측도(negative predictive value)를 95\% 신뢰 구간으로 분 석하였다.

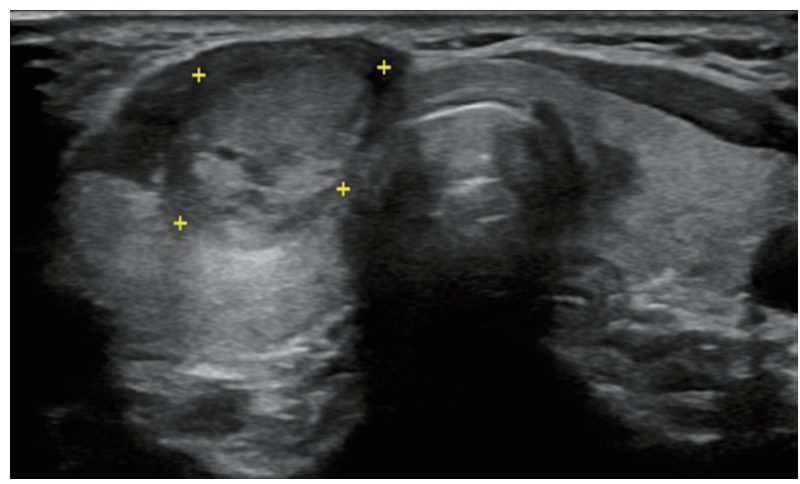

Fig. 3. Capsular protrusion (anterior region). Disruption of the perithyroidal echogenic line between the site of thyroid mass and the thyroid capsule as seen on ultrasonography.

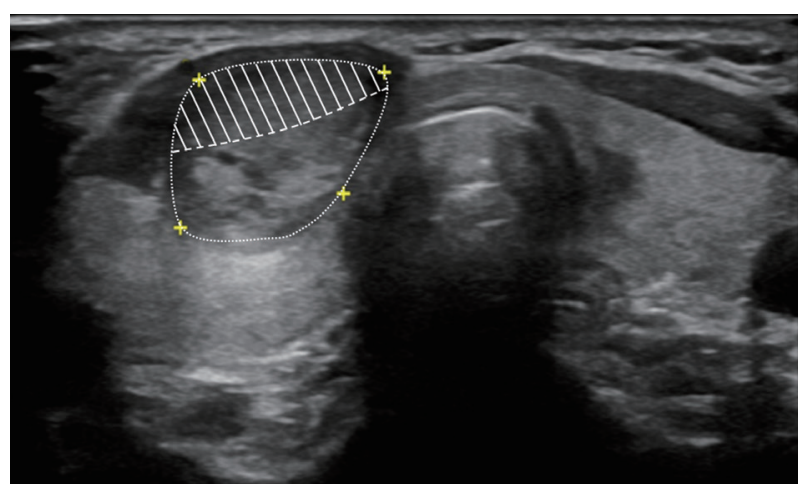

Fig. 4. The protrusion ratio [cross-sectional area of the protruding part (hatched area)/cross-sectional area of the entire mass (circle area)] of the mass that protruded the thyroid capsule was graded as less than $25 \%, 25 \%$ to $50 \%$, or greater than $50 \%$. 


\section{결 과}

수술 전 갑상선 초음파에서 종물의 크기가 $1 \mathrm{~cm}$ 이하인 군은 485 명이었고 이 중 27 명이 수술 중 육안적 피막 외 침윤 을 보였다. $1 \mathrm{~cm}$ 초과 $2 \mathrm{~cm}$ 이하의 군에서는 154 명 중 31 명, $2 \mathrm{~cm}$ 을 초과하는 군은 총 49 명 중 12 명이 각각 육안적 피막 외 침윤을 보였다. 종물의 크기가 커짐에 따라 육안적 피막 외 침윤이 많이 나타났으며 이는 통계학적으로 유의했다 $(p$ $<0.001$ ). 수술 전 초음파상 종물이 실질내 고립(isolation)되 어 있던 군 203명 중 5명에게서 수술 중 육안적 피막 외 침윤 이, 접촉(capsular contact) 군과 돌출(capsular protrusion) 군에서는 각각 348 명 중 34 명, 137 명 중 31 명에게서 육안적 피막 외 침윤이 확인되었고, 3 군 간의 유의미한 차이를 확인 할 수 있었다 $(p<0.001)$. 돌출 군 내에서 돌출의 정도 따른 차 이는 3 군에서 의미 있는 관계를 확인할 수 없었다 $(p=0.868)$. 종물과 피막이 접한 위치가 전방 접촉 군 174 명과 전방 돌출 군 110 명 중 접촉 군은 10 명이, 돌출 군은 21 명이 육안적 피막 외 침윤을 보여 유의성이 확인되었다 $(p<0.001)$. 하지만 종물 의 위치가 후방 접촉 및 돌출 군은 육안적 피막 침범의 유의 미한 차이가 없었다 $(p=0.146)$ (Table 1). 수술 전 초음파 검사 에서 종물이 갑상선의 전방으로 돌출하고 있는 경우, 초음파 검사의 육안적 피막 외 침윤의 민감도는 $58.3 \%$, 특이도 $80.3 \%$, 정확도 $78.6 \%$, 양성예측도 $19.1 \%$, 음성예측도 $96.0 \%$ 였다. 갑 상선 후방으로 종물이 돌출한 경우, 초음파 검사의 육안적 피 막외 침윤의 민감도 $34.4 \%$, 특이도 $84.4 \%$, 정확도 $80.7 \%$, 양 성예측도 $13.8 \%$, 음성예측도 $94.1 \%$ 였다.
나이, 성별, 키, 가족력, 수술 전 $B R A F$ 변이는 육안적 피막 외 침윤과 유의성이 없었다, 그러나 몸무게가 많고 체질량지 수가 높을수록 육안적 피막 외 침윤의 빈도가 증가하였다(각 각 $p=0.009, p=0.016$. 갑상선염이 없는 경우가 갑상선염이 있는 경우보다 육안적 피막 외 침윤이 유의하게 많았다 $(p<$ 0.001). 수술 범위가 커질수록, K-TIRADS가 5점일 때, 최종 병리 검사 결과상 $\mathrm{N}$ 병기가 높을수록 육안적 피막 외 침윤이 유의하게 많았다(각각 $p<0.001, p=0.047, p<0.001$ )(Table 2).

\section{고 찰}

갑상선 유두암의 수술 전 병기 설정은 수술의 범위를 결정 하는 데 매우 중요하며 특히 수술 전 초음파는 그 유용성이 입증되어 표준 검사 방법으로 추천하고 있다.9.10) 수술 전 초음 파는 종물의 크기, 위치, 다발성 여부, 경부 림프절의 전이 및 피막 외 침윤을 예측 해 볼 수 있으며, 환자 및 술자에게 수술 범위를 결정하는 근거를 제공할 뿐만 아니라 결과적으로 예 후에 큰 영향을 미칠 수 있기에 검사의 의의가 강조되고 있 다. ${ }^{11-13)}$ 여러 연구를 통해 피막 외 침윤의 평가는 과거 미세 피막 외 침윤보다는 육안적 피막 외 침윤이 중요하게 되었고, 최근 개정된 AJCC 8판에서도 육안적 피막 외 침윤을 중심으 로 $\mathrm{T}$ 병기를 분류하게 되었다. ${ }^{8)}$ 따라서 육안적 피막 외 침윤의 정확한 예측은 수술 전 갑상선 유두암 환자의 수술 범위 결 정에 매우 중요하다. 수술 전 초음파를 이용하여 미세 피막 외 침윤을 포함하는 피막 외 침윤의 예측에 대한 연구가 보고되 었으나 육안적 피막 외 침윤에 대해 수술 전 초음파로 예측한

Table 1. Ultrasonographic findings

\begin{tabular}{|c|c|c|c|c|}
\hline \multirow{2}{*}{ Preoperative ultrasonography findings } & \multicolumn{3}{|c|}{ Gross extrathyroidal extension } & \multirow{2}{*}{ p-value } \\
\hline & Positive & Negative & Total & \\
\hline Relationship with capsule & & & & $<0.001$ \\
\hline Isolation & $5(2.46)$ & $198(97.54)$ & 203 & \\
\hline Contact & $34(9.77)$ & $314(90.23)$ & 348 & \\
\hline Protrusion & $31(22.63)$ & $106(77.37)$ & 137 & \\
\hline Degree of protrusion & & & & 0.868 \\
\hline$<25$ & $21(22.82)$ & $71(77.18)$ & 92 & \\
\hline $25-50$ & $8(20.51)$ & $31(79.49)$ & 39 & \\
\hline$\geq 50$ & $2(33.33)$ & $4(66.66)$ & 6 & \\
\hline Contact site of capsule/anterior & & & & $<0.001$ \\
\hline Contact & $10(5.75)$ & $164(94.25)$ & 174 & \\
\hline Protrusion & $21(19.09)$ & $89(80.91)$ & 110 & \\
\hline Contact site of capsule/posterior & & & & 0.146 \\
\hline Contact & $20(8.77)$ & $208(91.23)$ & 228 & \\
\hline Protrusion & $12(13.79)$ & 75 (86.21) & 87 & \\
\hline
\end{tabular}

Data are expressed as the patients' number (percentage). Contact site of capsule/anterior: When the mass contacts (or protrudes into) the strap muscle. Contact site of capsule/posterior: When the mass contacts (or protrudes into) the trachea, esophagus, carotid sheath, or posterior soft tissue 
Table 2. Clinical and pathological factors

\begin{tabular}{|c|c|c|c|c|}
\hline \multirow{2}{*}{ Clinical factors } & \multicolumn{3}{|c|}{ Gross extrathyroidal extension } & \multirow{2}{*}{ p-value } \\
\hline & Positive & Negative & Total & \\
\hline Age & & & & 0.693 \\
\hline$>55$ & $41(9.81)$ & $377(90.19)$ & 418 & \\
\hline$\leq 55$ & $29(10.74)$ & $241(89.26)$ & 270 & \\
\hline Sex & & & & 0.211 \\
\hline Female & $53(8.85)$ & $506(91.15)$ & 599 & \\
\hline Male & $17(13.18)$ & $112(86.82)$ & 129 & \\
\hline Height, $\mathrm{cm}$ & 161.9 & 160.0 & & 0.229 \\
\hline Weight, kg & 65.5 & 60.5 & & 0.009 \\
\hline $\mathrm{BMI}, \mathrm{kg} / \mathrm{m}^{2}$ & 25.2 & 23.9 & & 0.016 \\
\hline Family history & & & & 0.836 \\
\hline Yes & $9(9.57)$ & $85(90.43)$ & 94 & \\
\hline No & $61(10.27)$ & $533(89.73)$ & 594 & \\
\hline$B R A F$ & & & & 0.339 \\
\hline Positive & $11(13.41)$ & $71(86.59)$ & 82 & \\
\hline Negative & $2(5.56)$ & $34(94.44)$ & 36 & \\
\hline Thyroiditis & & & & $<0.001$ \\
\hline Yes & $4(2.34)$ & $164(97.66)$ & 168 & \\
\hline No & $66(1.27)$ & $454(98.73)$ & 520 & \\
\hline K-TIRADS & & & & 0.047 \\
\hline 5 & $68(10.91)$ & $555(89.09)$ & 623 & \\
\hline $2-4$ & $2(3.08)$ & $63(96.92)$ & 65 & \\
\hline Surgery & & & & $<0.001$ \\
\hline Lobectomy/c CND & $5(1.82)$ & $270(98.18)$ & 275 & \\
\hline Total thyroidectomy/c CND & $44(12.64)$ & $304(87.36)$ & 348 & \\
\hline Total thyroidectomy/c CND/c ND & $21(32.31)$ & $44(67.69)$ & 65 & \\
\hline Tumor size, $\mathrm{cm}$ & & & & $<0.001$ \\
\hline$\leq 1$ & $27(5.57)$ & $458(94.43)$ & 485 & \\
\hline $1-2$ & $31(20.12)$ & $123(79.88)$ & 154 & \\
\hline$>2$ & $12(24.49)$ & $37(75.51)$ & 49 & \\
\hline$N$ stage & & & & $<0.001$ \\
\hline 0 & $29(6.39)$ & $425(93.61)$ & 454 & \\
\hline la & $24(13.56)$ & $153(86.44)$ & 177 & \\
\hline $1 b$ & $17(29.82)$ & $40(70.18)$ & 57 & \\
\hline
\end{tabular}

Data are expressed as the patients' number (percentage). Chi-square test or Fisher's exact test. BMI: body mass index, K-TIRADS: Korean Thyroid Imaging Reporting and Data System, CND: central neck dissection, ND: neck dissection

연구는 미미하다. Shimamoto 등르는 초음파 종물의 접촉과 돌출 모양에 따라 피막 외 침윤을 예측하고자 하였으며 $62.9 \%$ 의 민감도와 $97.6 \%$ 의 특이도를 보고했다. Kwak 등 ${ }^{14)}$ 의 연구 에서는 피막 접촉(contact) 정도가 $25 \%$ 이상일 경우 피막 외 침윤의 가능성이 높으며 $65.2 \%$ 의 민감도와 $81.8 \%$ 의 특이도를 보고했다. Park 등 ${ }^{11)}$ 은 종물과 피막이 $50 \%$ 이상 접할(abutment) 시 $74.5 \%$ 의 정확도로 피막 외 침윤이 있으며 $85.3 \%$ 의 민감도와 $70.0 \%$ 의 특이도를 보고했다. Lee 등 ${ }^{15)}$ 은 종물과 피막 접촉 정도를 25\% 미만, 25 50\% 그리고 50\% 초과의 3군 으로 세분하고 동시에 돌출 유무를 함께 평가하여 보다 광범
위한 기준을 적용하여 피막 외 침윤을 분석하였고, 피막 접 촉 비율이 증가할수록 피막 외 침윤의 가능성이 높으며 피막 접촉(contact)보다 피막의 돌출(protrusion)이 더 강한 예측 인자이며 $83.3 \%$ 의 민감도, $68.9 \%$ 의 특이도, $75.9 \%$ 의 정확도 를 보고하였다.

현재까지 갑상선 초음파를 이용하여 수술 전 피막 외 침윤 의 예측에 대한 연구는 미세 피막 외 침윤을 포함하는 연구가 대부분이다. 각 보고는 그 진단 기준이 다양하고 결과 역시 큰 차이를 보이는 문제가 있으며 미세 피막 외 침윤의 임상적 의미가 약한 현재의 가이드 라인에 적용하기에는 어려움이 
있다. 본 연구는 수술 전 초음파 영상을 통해 육안적 피막 외 침윤에 대한 예측을 분석한 연구이며, 피막 외 침윤과 함께 환자 병력을 기반으로 한 여러 매개 변수와 육안적 피막 외 침윤에 대한 상관성을 함께 확인한 연구이다.

본 연구에서는 수술 전 갑상선 초음파를 통해 종물의 크기, 종물과 피막과의 관계, 종물과 피막이 접한 위치, 종물이 피 막을 돌출한 정도를 확인하였다. 종물의 크기가 증가할수록 육안적 피막 외 침윤에 대한 상관성은 증가하였다(Table 2). 피막과의 관계를 고립, 접촉, 돌출 3 개의 군으로 나누어 분석 한 결과 육안적 피막 외 침윤은 돌출 군에서 유의성이 크다 는 것을 확인하였다(Table 1). 저자는 갑상선 종물의 위치에 따라 초음파 해석의 결과가 달라질 것이라 가정하여 종물이 피막과 접한 위치에 따른 육안적 피막 외 침윤에 대한 분석을 시행하였다. 종물이 갑상선의 전방에 위치하면서 피막과 접촉 또는 돌출된 경우, 접촉된 군보다 돌출된 군이 유의미하게 육 안적 피막 외 침윤이 많았다(Table 1). 하지만 종물이 갑상선 의 후방에 위치한 경우 피막과 접촉한 군과 돌출한 군의 차 이가 없었다. 본 연구에서는 수술 전 초음파에서 관찰되는 종 물이 갑상선 피막을 전방으로 돌출하는 경우, 육안적 피막 외 침윤에 대한 초음파 검사의 민감도가 $58.3 \%$, 특이도 $80.3 \%$, 정확도 $78.6 \%$, 양성예측도 $19.1 \%$, 음성예측도 $96.0 \%$ 였다. 갑 상선 후방으로 종물이 돌출한 경우 초음파 검사상 민감도 $34.4 \%$, 특이도 $84.4 \%$, 정확도 $80.7 \%$, 양성에측도 $13.8 \%$, 음 성예측도 $94.1 \%$ 를 확인할 수 있었지만 민감도가 낮고 후방 종물의 경우 접촉 군과 돌출 군 간의 통계적 차이가 없다는 점에서 의미 있는 결과가 아님을 알 수 있다.

초음파 검사는 갑상선 내부로 전파시킨 후 반사되어 나오 는 음파를 영상화하는 검사 방법으로 초음파 송수파기와 상 대적으로 가까운 갑상선 앞쪽 경계의 종물은 정밀한 관찰이 가능하나 상대적으로 거리가 먼 뒤쪽의 경계와 종물은 관찰 과 분석이 어려운 단점이 있다. 또한 종물이 크거나 초음파상 유두암에서 보일 수 있는 석회화 소견이 있는 경우는 후방 음 향 그림자(posterior acoustic shadowing)가 나타나 초음파 영상 분석에 어려움이 있을 수 있다. 이러한 이유로 종물의 위치에 따라 초음파 영상의 해석은 정확성이 달라질 수 있을 것이라 생각된다. 또한 갑상선 뒤쪽에 위치한 종물 중 주위 조직보다 상대적으로 단단한 기관지 연골과 종물이 접촉한 경우에서 피막 외 침윤을 평가할 시 단순히 종물과 피막의 접촉 정도로 평가할 것이 아니라 기관지 연골과 종물의 접촉 각도(둔각, 직각, 예각)에 따른 분석 ${ }^{16}$ 과 같은 구체적 방법의 추가적인 연구가 필요할 것으로 생각된다.

본 연구에서 수술 전 갑상선 초음파 검사는 갑상선의 전방 에 위치하는 종물의 육안적 피막 외 침윤 예측에는 유용하였
지만, 후방에 위치하는 종물에 대해서는 다시 예측이 힘들다 는 것을 확인할 수 있었다. 수술 전 갑상선 초음파를 이용해 피막 외 침윤을 진단할 때 현재까지 임상적으로 피막과의 접 촉 또는 돌출의 개념으로 종물을 분류하였다. Shimamoto 등른 갑상선 종물이 초음파상 주위 조직으로의 돌출이 있 는 경우 피막 외 침윤이 있는 것으로 정의하였다. 대조적으로 Kwak 등 (14)과 Park 등1ㅣ은 접촉의 관점에서 피막 외 침윤을 평가하였다. 최근 Lee 등 ${ }^{15)}$ 이 보고한 연구에서는 두 가지 모 두를 고려하여 평가하기도 하였다. 이러한 과거 연구들은 미 세 피막 외 침윤에 초점을 맞춰 초음파 분석을 보다 포괄적으 로 시행할 수 밖에 없었다. 하지만 육안적 피막 외 침윤을 예 측하는 데 있어서 과거 기준의 초음파 해석은 민감도를 낮추 고 위양성을 증가시켜 불필요한 갑상선 전절제술이 시행될 가능성이 높다. 최근 $\mathrm{Kim}$ 등 ${ }^{17}$ 의 연구에서는 초음파상 주위 구조물로 종물이 돌출된 상태는 가장 강력한 피막 외 침윤의 독립 인자라 보고하고 있으며 이에 따라 본 연구에서는 종물 의 돌출 정도에 초점을 맞추어 초음파 영상을 분석하였다. 하 지만 돌출된 정도와 육안적 피막 외 침윤 사이에서는 유의미 한 관계를 확인할 수 없었고, 이는 초음파상 적은 비율의 돌 출이라도 확인이 된다면 육안적 피막 외 침윤을 염두해 두어 야 할 것으로 생각된다(Table 1).

본 연구를 진행하며 추가적으로 환자의 병력과 관계된 매 개변수에 대해 육안적 피막 외 침윤에 대한 분석을 시행하였 다. 나이, 키, 성별, 갑상선 암의 가족력, BRAF 유전자 돌연 변이는 육안적 피막 외 침윤과 관계가 없었지만 몸무게가 많 을수록, 체질량 지수가 높을수록, 갑상선염이 없는 경우, $\mathrm{K}-$ TIRADS가 높을수록 육안적 피막 외 침윤과 연관성이 있었 다. 또한 육안적 피막 외 침윤이 있는 경우 수술의 범위가 넓 었고 N병기가 높은 경우가 많았다. 갑상선암의 가족력이 있 으면 일반적으로 미세 피막 외 침윤이 증가한다는 Nixon 등 ${ }^{18}$ 의 보고가 있지만 육안적 피막 외 침윤을 분석한 본 연구에는 의미 있는 결과를 보이지 않았다. 최근 Lee 등 ${ }^{19}$ 의 연구에서 갑상선 유두암 환자 중 $B R A F$ 유전자 돌연변이가 있는 군이 변이가 없는 군보다 수술 전 초음파를 통한 육안적 피막 외 침윤의 예측에 연관성 있다고 보고하였다. 그러나 본 연구에 서는 $B R A F$ 유전자 돌연변이와 육안적 피막 외 침윤은 연관 성이 없었다. 몸무게와 체질량 지수가 높을수록 육안적 피막 외 침윤이 많은 경향을 보이는 것은 비만할수록 갑상선 암이 보다 공격적이라는 다른 연구와 유사한 부분이 있어, 향후 추 가적인 연구가 필요할 것으로 생각된다. ${ }^{20,21)} \mathrm{Junik}$ 등 ${ }^{22}$ 의 연 구에서는 갑상선염이 있는 경우 생리 및 병리조직적 검사에서 갑상선암과 유사한 특성을 보인다 보고하였다. 환자가 갑상 선염이 있다면 수술 전 초음파 시행 당시 염증 반응에 의해 
검사상 종물과 피막의 경계가 모호해지며 염증이 심한 경우 종물이 피막 밖으로 돌출되어 보일 수 있다. 하지만 실제 수 술 시에는 유착 없이 잘 박리되어 주변 구조물로 침윤이 없는 경우가 많다. 그리고 일부의 연구에서 갑상선염이 있는 경우 림프절 전이가 적다는 보고도 있다. ${ }^{23)} \mathrm{K}$-TIRADS 및 N-stage 가 높을수록 병의 정도가 심하기 때문에 육안적 피막 외 침 윤은 예상과 같이 연관성을 확인 할 수 있었다. 또한 육안적 피막 외 침윤은 수술 중 외과 의사에 의해 주관적인 소견에 의해 판단하는 것으로 객관적인 소견이라기보다는 주관적인 견해가 포함될 수 있다. 향후 피막 외 침윤을 평가하는 보다 객관적인 방법이 필요할 것으로 생각된다.

결론적으로, 갑상선 유두암 환자의 수술 전 초음파 검사는 육안적 피막 외 침윤을 예측하는 데 매우 유용한 도구이며, 갑상선 종물이 갑상선의 전방에 위치한 경우 후방에 위치하 는 종양보다 육안적 피막 외 침윤을 예측하기가 용이하였다.

\section{Acknowledgments}

This work was supported by a 2-Year Research Grant of Pusan National University.

\section{Author Contribution}

Conceptualization: Hyo-Seok Seo, Yong-Il Cheon, Hyun-Keun Kwon, Sung-Chan Shin, Eui-Suk Sung, Jin-Choon Lee, Bo Hyun Kim, In Ju Kim, Byung-Joo Lee. Data curation: Hyo-Seok Seo, Yong-Il Cheon, Hyun-Keun Kwon, Sung-Chan Shin, Myeonggu Seo, Youngjin Cho, Eui-Suk Sung, Jin-Choon Lee, Bo Hyun Kim, In Ju Kim. Formal analysis: Hyo-Seok Seo, Hyun-Keun Kwon, Sung-Chan Shin, Eui-Suk Sung, Jin-Choon Lee, Bo Hyun Kim, In Ju Kim, Byung-Joo Lee. Investigation: Hyo-Seok Seo, Yong-Il Cheon, Hyun-Keun Kwon. Methodology: Hyo-Seok Seo, ByungJoo Lee. Supervision: Hyun-Keun Kwon, Sung-Chan Shin, Eui-Suk Sung, Jin-Choon Lee, Bo Hyun Kim, In Ju Kim, Byung-Joo Lee. Writing — original draft: Hyo-Seok Seo. Writing—review \& editing: Hyo-Seok Seo, Byung-Joo Lee.

\section{ORCIDs}

\section{Byung-Joo Lee}

Yong-Il Cheon

Hyun-Keun Kwon

Sung-Chan Shin

Eui-Suk Sung

Jin-Choon Lee https://orcid.org/0000-0001-7091-6688 https://orcid.org/0000-0003-0288-0542 https://orcid.org/0000-0003-4089-8639 https://orcid.org/0000-0003-2329-0648 https://orcid.org/0000-0001-8752-3426 https://orcid.org/0000-0002-4056-8763

\section{REFERENCES}

1) Sherman SI. Thyroid carcinoma. Lancet 2003;361(9356):501-11.

2) Stack BC Jr, Ferris RL, Goldenberg D, Haymart M, Shaha A, Sheth S, et al. American Thyroid Association consensus review and statement regarding the anatomy, terminology, and rationale for lateral neck dissection in differentiated thyroid cancer. Thyroid 2012;22(5):501-8.

3) Ganly I, Nixon IJ, Wang LY, Palmer FL, Migliacci JC, Aniss A, et al. Survival from differentiated thyroid cancer: What has age got to do with it? Thyroid 2015;25(10):1106-14.
4) Maino F, Forleo R, Pacini F. Prognostic indicators for papillary thyroid carcinoma. Expert Rev Endocrinol Metab 2017;12(2):101-8.

5) Lee YW, Kim TH, Jang HJ, Park MJ, Yeo CK. Sonographic index for extrathyroidal extension of papillary thyroid carcinoma. Korean J Otorhinolaryngol-Head Neck Surg 2015;58(9):622-7.

6) Martins AS, Melo GM, Valério JB, Langner E, Lage HT, Tincani AJ. Treatment of locally aggressive well-differentiated thyroid cancer. Int Surg 2001;86(4):213-9.

7) Park SY, Kim HI, Kim JH, Kim JS, Oh YL, Kim SW, et al. Prognostic significance of gross extrathyroidal extension invading only strap muscles in differentiated thyroid carcinoma. Br J Surg 2018;105(9):1155-62.

8) Amin MB, Edge S, Greene F, Byrd DR, Brookland RK, Washington MK, et al. AJCC cancer staging manual. Berlin: Springer;2017.

9) Yeh MW, Bauer AJ, Bernet VA, Ferris RL, Loevner LA, Mandel SJ, et al. American Thyroid Association statement on preoperative imaging for thyroid cancer surgery. Thyroid 2015;25(1):3-14.

10) Ahn SY, Park JJ, Ko ES, Jeon SY, Ahn SK, Kim DW, et al. The diagnostic values of ultrasonography in the papillary thyroid carcinoma. J Clinical Otolaryngol 2009;20(1):55-9.

11) Park JS, Son KR, Na DG, Kim E, Kim S. Performance of preoperative sonographic staging of papillary thyroid carcinoma based on the sixth edition of the AJCC/UICC TNM classification system. AJR Am J Roentgenol 2009;192(1):66-72.

12) Shimamoto K, Satake H, Sawaki A, Ishigaki T, Funahashi H, Imai T. Preoperative staging of thyroid papillary carcinoma with ultrasonography. Eur J Radiol 1998;29(1):4-10.

13) Choi JS, Kim J, Kwak JY, Kim MJ, Chang HS, Kim EK. Preoperative staging of papillary thyroid carcinoma: Comparison of ultrasound imaging and CT. AJR Am J Roentgenol 2009;193(3):871-8.

14) Kwak JY, Kim EK, Youk JH, Kim MJ, Son EJ, Choi SH, et al. Extrathyroid extension of well-differentiated papillary thyroid microcarcinoma on US. Thyroid 2008;18(6):609-14.

15) Lee CY, Kim SJ, Ko KR, Chung KW, Lee JH. Predictive factors for extrathyroidal extension of papillary thyroid carcinoma based on preoperative sonography. J Ultrasound Med 2014;33(2):231-8.

16) Miyauchi A. Clinical trials of active surveillance of papillary microcarcinoma of the thyroid. World J Surg 2016;40(3):516-22.

17) Kim SS, Lee BJ, Lee JC, Kim SJ, Lee SH, Jeon YK, et al. Preoperative ultrasonographic tumor characteristics as a predictive factor of tumor stage in papillary thyroid carcinoma. Head Neck 2011;33(12):1719-26.

18) Nixon IJ, Suárez C, Simo R, Sanabria A, Angelos P, Rinaldo A, et al. The impact of family history on non-medullary thyroid cancer. Eur J Surg Oncol 2016;42(10):1455-63.

19) Lee DY, Hwang SM, An JH, Son KR, Baek SK, Kim SG, et al. Predicting extrathyroidal extension in patients with papillary thyroid microcarcinoma according to a BRAF mutation. Clin Exp Otorhinolaryngol 2017;10(2):174-80.

20) He Q, Sun H, Li F, Liang N. Obesity and risk of differentiated thyroid cancer: A large-scale case-control study. Clin Endocrinol (Oxf) 2019;91(6):869-78.

21) Son H, Lee H, Kang K, Lee I. The risk of thyroid cancer and obesity: A nationwide population-based study using the Korea National Health Insurance Corporation cohort database. Surg Oncol 2018; 27(2):166-71.

22) Junik R, Juraniec O, Pypkowski J, Krymer A, Marszałek A. A difficult diagnosis: A case report of combined Riedel's disease and fibrosing Hashimoto's thyroiditis. Endokrynol Pol 2011;62(4):351-6.

23) Kim SS, Lee BJ, Lee JC, Kim SJ, Jeon YK, Kim MR, et al. Coexistence of Hashimoto's thyroiditis with papillary thyroid carcinoma: The influence of lymph node metastasis. Head Neck 2011;33(9):1272-7. 